\title{
Regional enteritis leading to carcinoma of the small bowel
}

\author{
A. P. WYATT \\ From the Memorial Hospital, Woolwich, London
}

SUMMARY A case of carcinoma of the small bowel intimately associated with long-standing regional enteritis (Crohn's disease) is described. Sixteen similar cases reported in the literature are briefly reviewed. This neoplasm presents at a younger age than other small bowel carcinomas and there seems little doubt that it is causally related to the inflammatory bowel lesion.

The aetiological factors in cancer of the bowel are not yet clear. In the colon there is, however, a known association with ulcerative colitis. This case report, with others in the literature, indicates that longstanding ulcerative and inflammatory disease in the small bowel is also in a proportion of cases followed by neoplastic change.

\section{CASE REPORT}

S.J.H., 33 years of age, a French polisher, was admitted in February 1968 for investigation of severe diarrhoea. His first attack of diarrhoea, which lasted for three months, had occurred seven years previously. For nine months after admission he had had eight to 10 bowel motions a day and had latterly become incontinent. Although the stools were watery he denied seeing any blood or mucus. He complained of vague abdominal pain and borborygmi and was anorexic. His weight had fallen by $40 \mathrm{lb}$ in the previous few months.

Examination revealed an extremely wasted man with poor dental hygiene. No abnormal physical signs could be elicited from chest or abdomen. On rectal examination there was some anal spasm and watery stool. Sigmoidoscopy showed hyperaemic mucosa but no tendency to bleed and no ulceration.

He was anaemic (haemoglobin $10.3 \mathrm{~g} / 100 \mathrm{ml}$, electrolytes within normal limits); no intestinal pathogens were isolated; serum proteins, total $5.4 \mathrm{~g} / 100 \mathrm{ml}$ (albumin $1.6 \mathrm{~g} / 100 \mathrm{ml}$, globulin $3.8 \mathrm{~g} / 100 \mathrm{ml}$ ). Alkaline phosphatase $50 \mathrm{KA}$ units $100 \mathrm{ml}$; total serum bilirubin $0.3 \mathrm{mg} 100 \mathrm{ml}$; SGOT 125 units, and SGPT 180 units. A barium meal showed a normal oesophagus, stomach, and duodenum, but the follow-through films showed abnormal small bowel with considerable dilatation and coarse mucosal folds. This appeared to begin in the lower jejunal region and extended down to the terminal ileum. The large bowel was also rather dilated and showed fluid levels in the erect position. A xylose excretion test was done: $9.2 \%$ of a $25 \mathrm{~g}$ dose had been excreted in five hours, a marked impairment. A duodenal biopsy was taken by Crosby capsule and showed thickening and flattening of the villi.

Treatment for a supposed malabsorption syndrome was instituted but his condition deteriorated further.

A barium enema was then done which showed an irregular channel from the right of the rectum communicating with the small bowel and the most probable diagnosis now seemed to be Crohn's disease of the ileum with an iliorectal fistula. By this time he was even weaker; he became occasionally confused and developed bronchopneumonia. Intravenous feeding with aminosol and intralipid, plasma and blood transfusions together with antibiotics resulted in some degree of improvement for three or four days but then his condition began to deteriorate again and immediate correction of the fistula seemed to offer the only hope of survival.

The abdomen was explored through a right paramedian incision. A grossly dilated loop of lower ileum was found firmly adherent to the pelvis. Below this was a stricture and then the final four or five inches of terminal ileum which were grossly thickened. On dividing the adhesions an ileal fistula and two iliorectal fistulae were apparent in the region of the stricture. The mesenteric glands were enlarged. The liver was pale and fatty. The lower two feet of ileum and the caecum, appendix, and ascending colon were resected and an end-to-end anastomosis was made. The patient recovered consciousness after the anaesthetic but despite intensive treatment he died the following day. At necropsy the cause of death was said to be bronchopneumonia.

\section{PATHOLOGY}

Study of the opened operation specimen showed the terminal ileum to be thickened and fibrotic with numerous pits and clefts in a rather smooth fixed mucosa; above this was a very narrow strictured region and above this again the greatly distended obstructed ileum showing gross cobblestone changes, ulceration, and pseudopolyps. Multiple small polyps 
arising on the crests of the rugae extended for some distance above the more obviously diseased bowel. Microscopy of the stenosed area showed ulceration of the mucosa with inflammatory cells in the submucosa and a generalized lymphadenoid change with clefting. In some areas, where the mucosa was intact, there was malignant change with extension of an acinar adenocarcinoma through the muscle to the subserosal fat. The related lymph nodes showed inflammatory changes with no evidence of growth. It was concluded that the specimen showed Crohn's disease of the ileum with carcinomatous change.

\section{OTHER REPORTED CASES}

Sixteen other cases of adenocarcinoma of the small bowel associated with Crohn's disease have been traced in the literature and are summarized in Table I. In addition two cases of reticulum cell sarcoma with Crohn's disease have been reported, one by Hughes (1955) and one by Wyburn-Mason
(1968), but there are no details of these cases available and they will not be discussed further.

Certain features are apparent in Table I. In every recorded case, except two, there is a history of bowel symptoms for several years before neoplastic change was discovered; in several of these patients radiological or surgical evidence of regional enteritis had been obtained many years before. Excluding the two patients with a three-month history or less, mean duration of symptoms is 15.7 years. The age at the time of diagnosis of malignancy is also remarkably young when compared with other series of small bowel carcinoma. The mean age in this series is 42.7 years. Brooks, Waterhouse, and Powell (1968), reviewing a series of 55 small bowel carcinomas, none of which was associated with Crohn's disease, found a mean age of $60 \cdot 8$ years. In Table II the ages of an expanded series of 119 cases of carcinoma of ileum and jejunum from the Birmingham Cancer Registry (Brooks, 1968) are compared in 10-year groups with

TABLE I

CASES OF CARCINOMA OF SMALL BOWEL ASSOCIATED WITH CROHN'S DISEASE

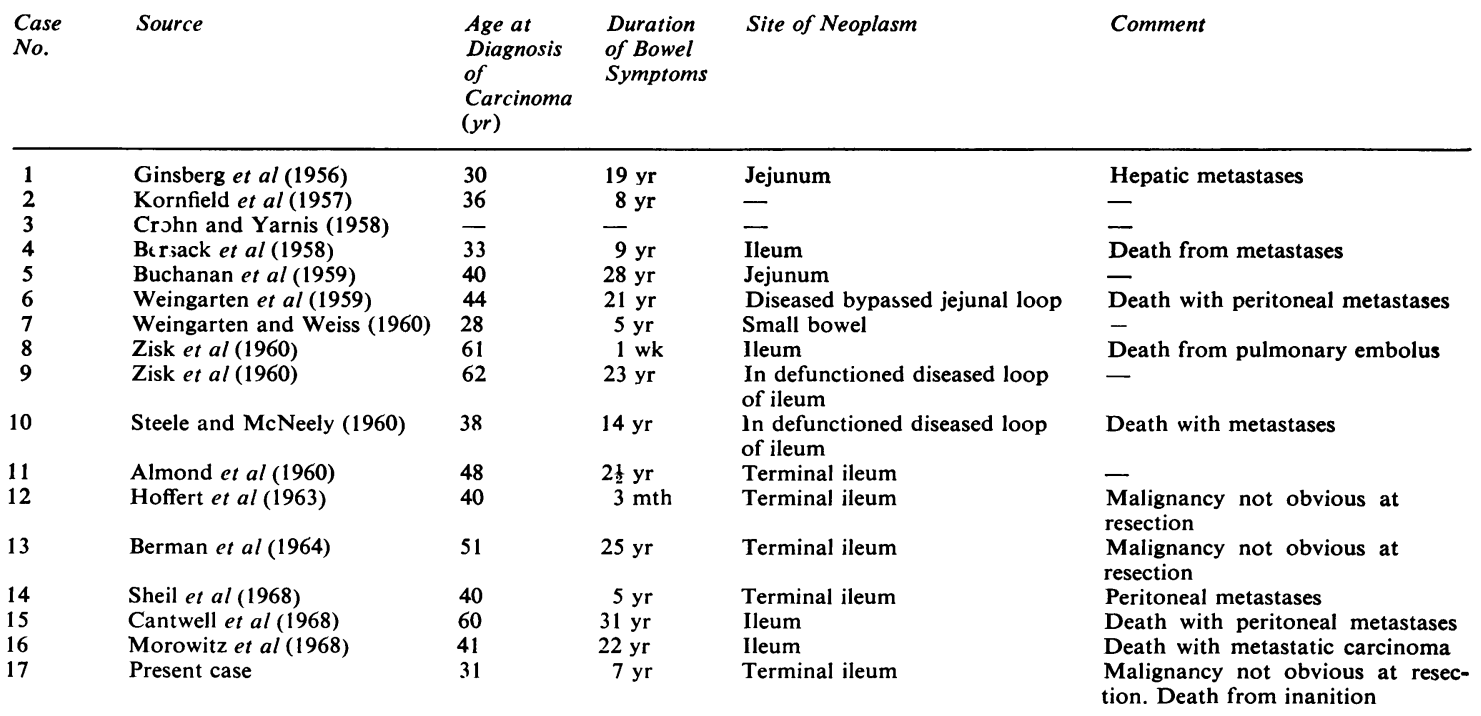

TABLE II

NUMBER OF CASES OF CARCINOMA OF SMALL BOWEL ALONE COMPARED WITH CARCINOMA ASSOCLATED WITH CROHN'S DISEASE OF SMALL BOWEL IN 10-YEAR AGE GROUPINGS

\begin{tabular}{|c|c|c|c|c|c|c|c|c|}
\hline \multirow[t]{2}{*}{ Series } & \multirow{2}{*}{$\begin{array}{l}\text { Total No. } \\
\text { of Cases }\end{array}$} & \multicolumn{7}{|c|}{ Age at Diagnosis of Neoplasm $(y r)$} \\
\hline & & $0-25$ & $26-34$ & $35-44$ & $45-54$ & $55-64$ & $65-74$ & $75+$ \\
\hline $\begin{array}{l}\text { Brooks (1968) } \\
\text { (Birmingham Cancer Registry 1950-1966) }\end{array}$ & 119 & 1 & 6 & 6 & 20 & 30 & 38 & 18 \\
\hline $\begin{array}{l}\text { Curwen (1968) } \\
\text { (St Bartholomew's Hospital 1948-1952) }\end{array}$ & 7 & - & 1 & 1 & 1 & 2 & 2 & - \\
\hline $\begin{array}{l}\text { Associated with Crohn's disease } \\
\text { (see Table I) }\end{array}$ & 16 & - & 4 & 7 & 2 & 3 & - & - \\
\hline
\end{tabular}

(see Table I) 
another small series, and with this group in which carcinoma is associated with Crohn's disease. The difference in age distribution is apparent. The prognosis in recorded cases has been poor; the cases have been reported early because they were thought to be of interest but even so at least seven patients of the series of 16 were dead, three directly of their malignancy.

In none of these cases was the diagnosis of carcinoma made preoperatively and in this case, as in cases $1,5,12$, and 13 , it was not obvious on macroscopic examination of the specimen but only on microscopy. Cases 6, 9, and 10 show that bypassing a diseased loop may leave a potentially dangerous situation in which malignancy may develop many years later.

\section{DISCUSSION}

Although it is accepted that there is an increased incidence of carcinoma of the colon in ulcerative colitis it is generally believed that no such association occurs in Crohn's disease. However, Perrett, Truelove, and Massarella (1968) have reported three cases of carcinoma of the colon associated with Crohn's disease of that organ and reviewed other cases in the literature. Their cases differed from these in that the granulomatous lesion was an incidental finding on operating to remove the carcinoma, quite the reverse of the present series, and none of their patients had a prolonged history of bowel disease before diagnosis of the carcinoma.

The sequence of events in this series is similar to that seen in ulcerative colitis where prolonged disease of the bowel may be followed many years later by carcinoma (De Dombal, Watts, Watkinson, and Goligher, 1966). Hinton (1966) quotes the clinical impression that young age at onset of colitis increases the risk, an impression also gained in this series where 12 of the 17 first had symptoms in the second or third decade of life.

From the paucity of reported cases it would appear that carcinomatous change in Crohn's disease of the small bowel is quite rare. In most series it does not feature at all. In a recently followed-up series of $\mathbf{3 0 2}$ cases of Crohn's disease (Murray, 1968), from King's College Hospital, London, there were six associated carcinomas, one each of oesophagus, stomach, rectosigmoid, rectum, kidney, and breast, but none of the small bowel. As already mentioned, the malignant lesion may not be macroscopically obvious so that a careful search of specimens with the possibility of malignancy in mind may result in more frequent diagnosis in the future.

The clinician, recognizing the possibility of malignant change, will be more inclined to offer ablative surgery in longstanding cases and avoid bypass procedures if at all possible.

I should like to thank Dr 1. Williams for the pathology report.

\section{REFERENCES}

Almond, C. H., Neal, M. P., and Moedl, K. R. (1960). Regional ileitis with coincident ileal carcinoma. Missouri Med., 57, $452-453$.

Berman, L. G., and Prior, J. T. (1964). Adenocarcinoma of the smal intestine occurring in a case of regional enteritis. J. Mt. Sinai Hosp., 31, 30-37.

Bersack, S. R., Howe, J. S., and Rehak, E. M. (1958). A unique case with roentgenologic evidence of regional enteritis of long duration and histologic evidence of diffuse adenocarcinoma. Gastroenterology, 34, 703-710.

Brookes, V. S., Waterhouse, J. A. H., and Powell, D. J. (1968). Malignant lesions of the small intestine: a ten-year survey. Brit.J. Surg., 55, 405-410.

(1968). Personal communication.

Buchanan, D. P., Huebner, G. D., Woolvin, S. C., North, S. C., and Novack, T. D. (1959). Carcinoma of the ileum occurring in an area of regional enteritis. Amer.J. Surg., 97, 336-339.

Cantwell, J. D., Kettering, R. F., Carney, J. A., and Ludwig, J. (1968) Adenocarcinoma complicating regional enteritis: report of a case and review of the literature. Gastroenterology, 54, 599-604.

Crohn, B. B., and Yarnis, H. (1958). Regional Enteritis, 2nd ed. p. 74. Grune and Stratton, New York.

Curwen, M. P. (1968). Personal Communication.

De Dombal, F. T., Watts, J. McK., Watkinson, G., and Goligher, J. C. (1966). Local complications of ulcerative colitis: stricture, pseudopolyposis, and carcinoma of colon and rectum. Brit. med.J., 1, 1442-1447.

Ginzburg, L., Schneider, K. M., Dreizin, D. H., and Levinson, C. (1956). Carcinoma of the jejunum occurring in a case of regional enteritis. Surgery, 39, 347-351.

Hinton, J. M. (1966). Carcinoma in ulcerative colitis. Proc. roy. Soc. Med., 59, 632-633.

Hoffert, P. W., Weingarten, B., Friedman, L. D., and Morecki, R. (1963). Adenocarcinoma of the terminal ileum in a segment of bowel with coexisting active ileitis. New York Med. J., $63,1567-1571$.

Hughes, R. K. (1955). Reticulum cell sarcoma: a case possibly originating in regional enteritis. Amer. Surg., 21, 770-773.

Kornfeld, P., Ginsburg, L., and Aldersburg, D. (1957). Adenocarcinoma occurring in regional jejunitis. Amer. J. Med., 23, 493-498.

Morowitz, D. A., Block, G. E., Kirsner, J. B. (1968). Adenocarcinoma of the ileum complicating chronic enteritis. Gastroenterology, 55, 397-402.

Murray, I. (1968). Personal communication.

Perrett, A. D., Truelove, S. C., and Massarella, G. R. (1968). Crohn's disease and carcinoma of colon. Brit. med. J., 2, 466-468.

Sheil, F. O'M., Clark, C. G., and Goligher, J. C. (1968). Adenocarcinoma associated with Crohn's disease. Brit. J. Surg., 55, 53-68.

Steele, D. C., and McNeely, D. T. (1960). Adenocarcinoma arising in a site of chronic regional enteritis. Canad. med. Ass. J., 83, 379-381.

Tyers, G. F. O., Steiger, E., and Dudrick, S. J. (1969). Adenocarcinoma of the small intestine and other malignant tumors complicating regional enteritis. Ann. Surg., 169, 510-518.

Weingarten, B., Parker, J. G., Chazen, E. M., and Jacobson, H. G. (1959). Adenocarcinoma of the jejunum in nonspecific granulomatous enteritis. Arch. Surg., 78, 483-489.

- , and Weiss, J. (1960). Malignant degeneration in chronic inflammatory disease of the colon and small intestine. Amer. J. Gastroent., 33, 203-207.

Wyburn-Mason, R. (1968). Crohn's disease and carcinoma of colon. (Letter). Brit. med.J., 2, 697.

Zisk, J., Shore, J. M., Rosoff, L., and Friedman, N. B. (1960). Regional enteritis complicated by adenocarcinoma of the ileum: a report of two cases. Surgery, 47, 970-974. 


\section{ADDENDUM}

Since writing this report a further case has been published (Tyers, Steiger, and Dudrick, 1969) of carcinoma developing in a defunctioned loop of jejunum in a man of 32 who had had symptoms of regional enteritis for 12 years.

\section{The October 1969 Issue \\ THE OCTOBER 1969 ISSUE CONTAINS THE FOLLOWING PAPERS}

Measurement of blood and iron loss in colitis with a whole-body counter B. H. R. STACK, T. SMITH, J. HYWELL JONES, and J. FLETCHER

Gastric acid secretion in patients with duodenal ulcer treated for one year with anticholinergic drugs MICHAEL D. KAYE, PETER BECK, JOHN RHODES, and PETER $M$. SWEETNAM

Gastric secretion after massive small bowel resection COLIN W. O. WINDSOR, J. FEJFAR, and D. A. K. WOODWARD

Use of an inert marker (phenol red) to improve accuracy in gastric secretion studies M. HOBSLEY and W. SILEN

Secretory response to secretin in a patient with diarrhoea and the Zollinger-Ellison pattern of gastric secretion H. PETERSEN, J. MYREN, and I. LIAVAG

The Zollinger-Ellison syndrome in a child H. B. C. BURMESTER, R. HALL, and N. MUNAWER

The paneth cell in disease KLAUS LEWIN

Studies on the intestinal flora B. S. DRASAR and MARGOT SHINER

Part II Bacterial flora of the small intestine in patients with gastrointestinal disorders

Significance of early and late positive responses to insulin hypoglycaemia in patients with intact vagi G. P. BURNS, F. C. Y. CHENG, A. G. COX, R. A. PAYNE, J. SPENCER, and R. B. WELBOURN
Insulin response to carbohydrate ingestion after gastric surgery with special reference to hypoglycaemia A. J. CAMERON, J. P. Ellis, J. I. MCGILl, and L. P. LE QUESNE

Severe peptic oesophagitis P. L. BRUNNEN, A. M. KARMODY, and C. D. NEEDHAM

The high incidence of intestinal volvulus in Iran FARROKH SAIDI

A new method for studying gut transit times using radioopaque markers J. M. HINTON, J. E. LENNARDJONES, and A. C. YOUNG

Oesophageal manometric studies in patients with chronic Chagas disease and megacolon PETER HEITMANN and JULIO ESPINOZA

Effect of $p H$ changes on the cardiac sphincter $G$. $R$. GILES, C. HUMPHRIES, M. C. MASON, and C. G. CLARK

\section{Progress Reports}

The importance of keeping bile salts in their place K. W. HEATON

The implications of bile in the stomach G. J. COLE

Comment

Notes and activities 